\title{
Analysis on Difficulties of Early Childhood Teachers in Assessing Early Childhood Development
}

\author{
Stephanus Turibius Rahmat ${ }^{1}$, Fransiskus De Gomes ${ }^{2}$, Ignasius Febryanto R. Bora ${ }^{3}$, Elfrida \\ Riani Tari ${ }^{4}$ \\ Program Studi PG PAUD, FKIP, Universitas Katolik Indonesia Santu Paulus Ruteng ${ }^{1234}$ \\ \{stephan_rahmat@yahoo.com\}
}

\begin{abstract}
Teachers often have difficulty in assessing early childhood development because the assessment aspects are too complex and abstract. This fact was experienced by early childhood education teachers in Boleng Subdistrict, West Manggarai Regency, NTT. Therefore, this study aims to find and describe the type of teacher's difficulties and their causative factors in assessing early childhood development. Researchers using qualitative methods with research subjects of those teachers in Boleng Subdistrict. The data collection techniques used in this study are questionnaires and document studies. Data analysis using model techniques developed by Miles and Huberman. The results of this study found out four categories of difficulty of teachers in assessing aspects of early childhood development, namely: teachers are less able to make planning assessments of early childhood development appropriately and correctly; teachers are less able to record or collect comprehensive child development data; teachers do not perform data processing and measurement of results continuously and are not based on complete data; teachers' reports of early childhood development assessment results made in the form of descriptions, making it difficult to understand the trends of children's development all the time. Meanwhile, the factors that make teachers having difficulties in assessing early childhood development are the pedagogical competences of teachers, the academic qualifications of teachers who are not in accordance with the professional guidance of early childhood education teachers, and the lack of fighting power of teachers in developing their competencies.
\end{abstract}

Keywords: assessment; teachers; developmental; education; early childhood

\section{Introduction}

Early Childhood development assessment is an integral fundamental component of learning activities in Early Childhood Education institutions. The assessment aims to find the level of developmental achievement of a child. The achievement of such development will determine the level of participation of children socially, physically and intellectually (Ngoun et al., 2020). Permendikbud Number 137, 2014 on National Standards of Early Childhood Education confirms that assessment is an important part of the learning process in Early Childhood Education (Kemendikbud Republik Indonesia, 2014c).

Pedagogic competency standards of early childhood education teachers state that a teacher must have three (3) competencies, first, conducting and making assessment reports, evaluating early childhood learning processes and outcomes; second, determine the scope of assessment goals of early childhood learning processes and outcomes; third, using the results of development assessment and evaluation of the program for the benefit of early childhood development. In this context, assessment is a systematic and continuous activity to select, collect 
and interpret data process and learning outcomes as important information about the learning development of learners (Ntuli et al., 2012; Varela Londoño et al., 2019).

Furthermore, this evidence becomes the basis for assessing the success of learning activities based on certain criteria. In addition, the information becomes the basis for making follow-up decisions to improve or increase the quality and quantity of learning outcomes. Early childhood development assessment should be based on criteria of children's learning processes and outcomesassessment (Wolf et al., 2017). This aims to meet the standards of achievement level of children development which are appropriate to their age. Assessment of early childhood learning processes and outcomes includes assessment on principles, assessment on techniques and instruments, assessment on mechanisms, assessment on implementation and reporting on assessment results.

Assessment of early childhood development needs to be done in order to assist the child's development at all stages. This is carried out because the learning activities in early childhood education are holistic and unique when compared to other levels of education (Carol S. Lidz, 2003;Catherine E. Snow and Susan B. Van Hemel, 2008).Early childhood development assessment is holistic because it assesses all aspects of child development (Rao et al., 2019; Owen \& Barnes, 2021). The uniqueness of learning in early childhood education is based on unique characteristics of children.

Early childhood is a different individual, unique, has its own characteristics, specific growth and development patterns according to their growth and development rate (Varela Londoño et al., 2019; Syafdaningsih, 2020; Owen \& Barnes, 2021).In addition, the uniqueness of early childhood is reflected in the characteristics of the six aspects of its development, namely aspects of religious and moral values, motor physics, cognitive, language, socio-emotional, and art(Kemendikbud RI, 2014;Jones et al., 2016;Rhoad-Drogalis et al., 2018;Khatib et al., 2020;Pushparatnam et al., 2021).Therefore, stimulation activities in early childhood education is aim on developing aspects of child development that are abstract and sustainable. Careful procedures and systematic, focused and comprehensive measurement and assessment of the instruments are needed to develop and assess these vital aspects.

This complex area of early childhood development has an effect on aspects of each assessment. Therefore, the scope of early childhood assessment should cover six aspects of the child's development (Carol S. Lidz, 2003; Jones et al., 2016). The assessment of early childhood development is holistic in quality, in order to achieve the actual goals or objectives of the assessment. In addition, the implementation of early childhood development assessment is carried out gradually and continuously so that teachers could know the progress of learning and child development (Wulansari, 2018). The complex process of assessing early childhood development requires early childhood education teachers withcertain pedagogical and professional competencies (Kim \& Han, 2015;Lee \& Recchia, 2016;Mundia \& Heru, 2020).

Previous research related to the topic of early childhood development assessment focuses more on conceptual and methodological issues on social, cognitive and emotional developmental measuresof early childhood (Jones et al., 2016). In this sense, the completely research does not specifically examine about the difficulty of teachers in assessing the early childhood development. Early childhood development assessment should be holistic, covering six aspects of early childhood development. It means that the assessment on child's development must be complicated because it considers various child's aspects (Rao et al., 2019). The assessment of early childhood development is important because it is considered as a milestone that determine the life and environmental level of the next child's participation socially, physically, and intellectually (Ngoun et al., 2020). 
There are a number of studies that show that teachers do not possess pedagogical and professional competence in assessing early childhood development yet. Teachers have not been able to assess the development of early childhood continuously, assessment has not been in accordance with the correct procedures and teachers do not systematically assess the development of children (Mundia \& Heru, 2020). On this matter, teachers usually only apply one form of assessment, namely the assessment of children's portfolios. It shows that teachers have not used a holistic and thorough form of assessment. Teachers only assess certain aspects of child's development such as language or cognitive or an art (Sum et al., 2020). The reason is because early childhood education teachers do not possess an educational background in terms of teaching and educating early childhood. Teachers educate and teach early childhood by relying on empirical experience when educating their own children (Maman et al., 2016).

In this study, researchers wanted to find and describe the types of difficulties and causes of teacher difficulties in assessing early childhood development. Based on the results of studies taken from several journals and observations that have been conducted at early childhood education institutions in Boleng Subdistrict, researchers studied the ability of teachers in measuring and assessing early childhood development and categorized it in low level. This is characterized by the poor ability of teachers in developing early childhood assessment instruments in accordance with the standards stated on Permendikbud, Number 137, 2014.The low competence of teachers in assessing early childhood development actually results in undocumented child development data. Furthermore, teachers who are less able to develop instruments and make assessments result in child development data recorded in the development recap (development report card), based on inaccurate measurement and assessment. As a result, the stimulation provided by the teacher is not in unity with the actual child's developmental condition.

Early childhood teachers in Boleng sub-district are less able to assess early childhood development due to three (3) reasons, namely first, aspects of children's development that are considered as comprehensive and abstract. There are six aspects of early childhood development, namely moral-religious, physical-motor, cognitive, language, socio-emotional, and art-creativity aspects. Moreover, to the physical-motor development aspects, the other five aspects of child development are considered abstract, making it difficult for teachers to measure and assess. Second, most teachers do not have adequate competence to measure and assess early childhood development. Third, lack of available references related to measurement instruments and assessment of early childhood development aspects.

Based on these problems, the research question of this study: (1) What are the difficulties of teachers in Boleng Subdistrict in assessing early childhood developmentaspects? (2) What causes teachers in Boleng Subdistrict having difficulty in assessing aspects of early childhood development? Based on this research questions, this study aims to find and describe the difficulties of teachers and their causative factors in assessing aspects of early childhood development.

\section{Literature Review}

The development of fundamental aspects in early childhood is largely determined by the stimulation provided by the teacher during learning processes. The provision of stimulation in early childhood education aims to develop child development aspects that are unique, holistic, abstract and sustainable. This is the uniqueness of learning in early childhood education compared to the primary and secondary education level. The peculiarities of early childhood education are based on the unique characteristics of the child. Early childhood has a specific pattern of growth and development according to its growth and development rate. Early 
childhood is an individual who is undergoing a process of rapid development thatis fundamental for further growth (Patricia et al., 2019). Early childhood is stated in a range of 0 to 6 years old. At this time, the process of growth and development of a child in various aspects takes place so quickly. Therefore, the learning process as a form of treatment given to the child should settlemore focuson the characteristics of each stage of the child's development.

Another study explains that early childhood is an individual who is undergoing a very rapid process of growth and development, even referred as a 'leap in development'(Brian Reichow, Brian A. Boyd Erin E. Barton, 2016).Early childhood has a very valuable age range compared to the later ages because the development of intelligence is very remarkable. At this age, a child is in a unique phase of life and in the process of changes, in the form of growth, development, maturation and refinement, both in the physical aspect and spiritual aspects that last for a lifetime, gradually and continuously. Early childhood is considered as a different or unique individual because it has its own characteristics according to the stage of its age.

The uniqueness of early childhood is reflected in the characteristics of the six aspects of its development (Kemendikbud Republik Indonesia,2014a; Joneset al.,2016;Rhoad-Drogalis et al.,2018; Khatib et al., 2020; Pushparatnam et al., 2021), namely:

First. Aspects of religious and moral values include the ability to know the religious values, carry out worship, be honest, helper, polite, respectful, sportsmanship, maintain personal and environmental hygiene, knowingon religion, respect, and tolerant forthe other religion.

Second. Physical-motor aspects include rough motor, fine motor aspects, health and safety behavior. Rough motor includes the ability of body movement in a coordinated, flexible, balanced, agile, locomotor, non-locomotor, and follow the rules. Fine motor includes the ability and flexibility of using fingers and tools to explore and express the body in a variety of forms. Health and safety behaviors include weight, height, age-appropriate head circumference and the ability to behave cleanly, healthily, and care for their safety.

Third. Cognitive aspects include learning and problem solving, logical thinking, and symbolic thinking. Learning and problem solving include the ability to solve simple problems in everyday life, in a socially flexible and accepted way and apply knowledge or experience in a new context. Logical thinking includes differences, classifications, patterns, initiatives, planning, and knowing causation. Symbolic thinking includes the ability to recognize, mention, and use the concept of numbers, recognize letters, and be able to represent various objects and imagination in the form of images.

Fourth. Language musty includes understanding receptive language, expressing language, and literacy. Understanding receptive language includes the ability to understand stories, commands, rules, enjoyment and appreciate reading. Expressing language includes the ability to ask questions, answer questions, communicate verbally, retell the known, learn pragmatic language, express feelings, ideas, and desires in the form of scribbles. Literacy, including understanding the relationship of letter shapes and sounds, mimicking letterforms, and understanding words in stories.

Fifth. Social-emotional aspects include self-awareness, a sense of responsibility for oneself and others, and pro-social behaviour. Self-awareness consists of showing self-ability, knowing one's own feelings and self-control, and being able to adjust to others. A sense of responsibility for oneself and others includes the ability to know their rights, obey the rules, govern themselves, and be responsible for their behaviour for the good of others. Prosocial behaviour includes the ability to play with peers, understand feelings, respond, share, and respect the rights and opinions of others; be cooperative, tolerant, and behave politely. 
Sixth. Aspects of art include the ability to explore and express themselves, imagine with movement, music, drama, and various other fields of art (painting, fine arts, crafts), and able to appreciate works of art, motion and dance, as well as drama.

This complex aspect of early childhood development has an impact on the scope of its assessment. Therefore, a teacher must master the scope of developmental assessment, developmental assessment objectives, principles of quality assessment, as well as assessment measures for early childhood development. Early childhood development assessment includes information about the child's increasing psychic and physical functions which include sensory(hearing, seeing, fingering, feeling and inhaling), motor (rough and smooth motor movements), cognitive (knowledge, intelligence), communication (speaking and language), as well as religious, socio-emotional and creativity attitudes formulated in the competencies of attitudes, knowledge and skills (Catherine E. Snow and Susan B. Van Hemel, 2008;Jones et al., 2016).

These six aspects must be stimulated and assessed proportionally and comprehensively in the early years of a child's development (Kamppi \& Gilmore, 2010). Early childhood development assessment is directed to achieve the following four (4) objectives(Carol S. Lidz, 2003; Kusaeri \& Suprananto, 2012; Thakkar et al., 2021), i. e. : (1) keeping track, which is an effort aimed at keeping the learning process in accordance with the plan, (2) checking-up, namely to check the weaknesses experienced by the teachers and early childhood during learning process, (3) finding out, namely to find the cause of weaknesses in the learning process, and (4) summing-up, namely to conclude and ensure the achievement of early childhood learning competencies.

Quality early childhood development assessment must meet seven (7) principles (Santrock, 2010; Brian Reichow, Brian A. Boyd Erin E. Barton, 2016), that is, (1) Valid. Assessment of early childhood learning by teachers must measure the achievement of competencies set out in content standards (standard competencies and basic competencies) and standard competency of graduates. The validity of the assessment is largely determined by a valid and reliable instrument; (2) Objective and fair. The early childhood assessment shouldn't be done in unfairness. The outcomes of this matter should not be influenced by the subjectivity of the assessor, differences in religious background, socio-economic, cultural, language, gender, and emotional relationships. Fair assessment means if all children get the same opportunity to learn and demonstrate abilities and assess the ability of early childhood objectively. Objective assessments would transpire if the teacher uses a clear assessment guide;

(3) Transparent. Assessments are conducted in accordance with the legal procedures and assessment results can be accessed by parents and all relevant stakeholders. Information obtained from the assessment results would become knowledge for parents about their child's development; (4) Accountable. Assessment is carried out in accordance with clear procedures and criteria. It can be accounted for in terms of techniques, procedures, and results; (5) Integrated. Assessment of learning outcomes as one of the integral components of learning activities. Further, the assessment must be integrated in the learning activities; (6) Comprehensive, systematic and sustainable.

A comprehensive learning assessment means an assessment covers all aspects of competence by using a variety of appropriate assessment techniques to monitor the development of early childhood abilities. Meanwhile, systematic and continuous assessment means that assessment must be conducted in a planned, gradual, and continuous manner by following the standard levels to obtain a comprehensive picture of the development of early childhood learning abilities all the time; (7) Educate. The process and results of learning assessment of children should contribute positively to their learning development and become the basis for 
motivating, developing children's learning. The assessment does not intend to judge early childhood, but for an educational purpose. These seven principles become the basis for assessing the process and learning outcomes of early childhood. If the teacher does not apply these seven principles in making assessments for the learning process and its results, then the learning becomes less meaningful. Therefore, a teacher must put forward these principles in making an assessment of the process and learning outcomes for early childhood.

A teacher should also be aware of the assessment measures for early childhood development. Permendikbud Number 137, Year 2014 on National Standards of Early Childhood Education in Chapter VI Article 21 (Kemendikbud Republik Indonesia, 2014a)explaining that the mechanism of assessment for early childhood development, namely (1) preparing and agreeing on the stages, techniques, and assessment instruments and establishing indicators of child development achievement as well;(2) carrying out the assessment process in accordance with the stages, techniques, and assessment instruments;(3) documenting the assessment for the child's learning process and results in an accountable and transparent manner;(4) reporting the child's developmental achievements to parents.

The assessment of early childhood development stated in the 2013 Curriculum of Early Childhood Education (Kemendikbud Republik Indonesia, 2014b; Kemendikbud Republik Indonesia, 2015; Syafdaningsih, 2020)is conducted with the authentic assessment through the following stages:

First, planning. At this stage, the activities that should carried out: (1) Determining basic competencies and formulating activities, namely (a) drawing up a Daily Learning Implementation Plan by focusing on determining aspects to be assessed. In the Daily Learning Implementation Plan there is a section called the assessment plan that contains what attitudes, knowledges, and skills would be seen in the child; (b) the number of elements assessed is based on one indicator of each domain's: attitude, knowledge, and skills. If the teachers are familiar with the authentic assessment process, then the number of indicators assessed could increase. For example, one element of attitude, one indicator of skill, and two indicators of knowledge. (2) Define assessment tools and criteria. The determination of the assessment tool must be adjusted to the indicators set out in the Daily Learning Implementation Plan. Assessment criteria are considered as a benchmark of the child's success, the determination of criteria must pay attention to the child and the time provided to gain such abilities; (3) Determine the best time and place.

Second, the implementation of early childhood development assessment. Teachers carry out early childhood development assessments based on the descriptions of growth and development, as well as child performances obtained using various assessment techniques. In the daily learning activities, the use of various assessment techniques is integrated with the learning activities. Assessment on early childhood education is conducted by techniques such as: (1) observation. It is made by the teachers directly and naturally to obtain data or information about children's development and problems in various situations and activities conducted. Observation can be done by observing various behaviours or changes that occurred or shown by the child during a certain period of time. Teachers can apply instruments during observation so that it can be directed while referring to the indicators of child development achievement. The most important aspect in assessing children is to make observations.

(2) Diary. The teacher keeps a diary during observations while the child is playing. If one child is enough on this matter, then the teacher give focus on several children in each day in turn. Thus, in one week (sub-theme), all children have been observed and their development recorded in the diary. Subjects to note in keeping a diary, namely (a) notes are not based on assumptions (from the observer's point of view), i. e.: "Budi is aggressive, bored, angry, etc.". 
(b) Do not use subjective and ambiguous words, i. e.: "Yani plays messy. He uses too many toys." (c) Record the immediate events at the time of the event. Therefore, teachers should always carry a booklet in their pocket and record key words related to what is observed. If that is not possible, then immediately take note of the time the child comes home. (d) Write down the name and age of the child, date/time, scene, and observed events. (e) Study basic competencies and developmental indicators, determine which basic competencies and developmental indicators are relevant to the events on the assessment.

Third, the processing of learning outcomes. The combination of data collected through observations written in anecdotal records and children's record sheet is processed to perceive the development of children's learning outcomes. This is handled by the teacher with aim to analyse the best development achieved by the child. The results of merging learning data can be included in the checklist. Checklist is a recording device that observe aspects of early childhood development. It contains developmental indicators for each basic competency of early childhood. The checklist results are also a matter of communication with parents about everything the child has learned and how the child make progress in learning. All data, information or data collection about the children in the portfolio needs to be processed for regular analysis. This data is needed so that teachers can do monthly assessments. Monthly processing results become the basis for conducting term assessments.

Fourth, reporting the results of the assessment. Before making a report, teachers conduct data collection activities in accordance with the objectives that have been settled in the form of teacher descriptions, children's work and others. All of these matters should be adapted to the data collection tools set out in the planning. Teachers process the data obtained and describe the results of the evaluation. Using this, teachers will get an overview about children's development related to the early childhood's learning. The teacher writes down the results of the processing and description in the child's education report. Reporting is an activity to explain the results of teacher assessments based on the growth and development of children which include the formation of basic behaviours and abilities. This report will explain to the parents and others who need children's growth and development results achieved by the children during their education processes. This report is described as effective as possible, so as not to cause misperceptions for parents or guardians or for those interested. Based on the results or summary of the growth and development of learners on certain time, the assessment is formed in a brief description of every aspect of the child's development.

The results of teacher assessment on early childhood development for one semester are recorded in the early childhood development report book by the following criteria (Kemendikbud Republik Indonesia, 2015): First, the report contains strengths and recommendations. Strengths are taken from the Develop as Expected and Excellent Progress Columns in the recapitulation of the last monthly assessment; Second, the recommendations contain advices that parents can address to the child at the time of parenting, taken from the Undeveloped and Still Developing Column in the last monthly assessment recap and the previous one. Third, a general description of the child's development; Fourth, the description of the progression children's abilities that are included in the classification of Developing Very Well and Developing as Expected and Classification that has not developed on all aspects of development.

Teachers or principal create a verbal or written report regarding the early childhood development. The child's progress can be done directly or in the form of a written report to the parents. In this case, teachers and early childhood parents need to build an intensive communication. Thus, reciprocal information actually occurs between early childhood education institutions and parents. In the implementation of reporting activities, teachers should 
maintain the confidentiality of data or information about children. The teacher only reports the child's development to the child's parents or experts in order to provide further guidance. Teachers must express, prove, or demonstrate appropriately to show that the competencies are truly mastered and achieved at an early age.

This systematic and complex early childhood development assessment process requires early childhood education teachers who possess pedagogical, professional, personal, and social competencies. Lacking these competences for teachers will affect the assessment process of early childhood development. This leads to undocumented early childhood development data. Thus, the stimulation provided by the teacher is not in accordance with the situation and actual developmental condition of the child.

\section{Research Methods}

\section{Research design}

This study applies descriptive quantitative method, with some reasons: (1) to find and describe the types or factors that cause difficulties for early childhood education teachers in Boleng Subdistrict in assessing the development of early childhood; and (2) types of data collection are categorized as quantitative data in the form of percentage of teacher's ability to develop and assess early childhood development. This research was conducted in early childhood education institutions in Boleng Sub-district, West Manggarai Regency.

\section{Participants}

The subjects of this study were early childhood education teachers in Boleng Subdistrict which numbered 32 people.

\section{Data Collection}

Data collection is done using questionnaires techniques and document studies. The research instrument uses questionnaire sheets and the format of early childhood development assessment documents. These instruments were developed with reference to the focus of the problem studied. Before analysing the data, the researchers examined the validity of the data with crosscheck techniques. This is to ensure that data collected is accurate.

\section{Data Analysis}

Next step, researchers analysed the data using the Miles and Huberman Models (Matthew B.Miles, A. Michael Huberman, 2014).This model consists of four (4) stages, namely Data Collection, Data Condensation/Data Reduction, Display Data, Conclusions: Drawing/verifying. Data condensation is done by selecting, focusing, simplifying, abstracting, and changing field notes, documents, and other empirical materials (findings). In other words, data condensation aims to categorize data on relevant or irrelevant data with research focus. Irrelevant data is ignored in analysis.

Furthermore, data relevant to the research focus is presented based on codes consisting of background/context codes, process codes, activity codes, event codes, strategy codes, relationship and social structures codes and narrative codes. Then, the researchers drew inductive conclusions from the data sets that had been presented in each code. Interactive analysis flowchart developed by Miles and Huberman (2014) as follows: 


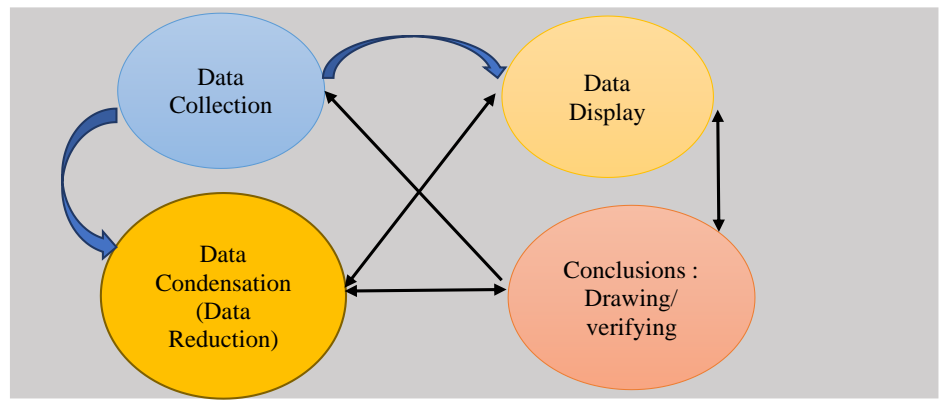

Fig 1. Miles and Huberman Interactive Analysis Flowchart (Matthew B.Miles, A. Michael Huberman, 2014, p.33)

\section{Results and Discussion}

Two main things described in this study, namely the types and factors that cause teachers to have difficulty assessing early childhood development.

\section{Types of Difficulties of Early Childhood Education Teachers}

The difficulty of teachers in assessing the development of children in early age is shown in tables 1 and 2 below:

Table 1. Types of Difficulties for Teachers in Assessing Early Childhood Development with Questionnaires

\begin{tabular}{|c|c|c|c|}
\hline No. & Assessed Aspects & Sub-sub-Aspects Assessed & $\begin{array}{l}\text { Respondent } \\
\text { Achievement } \\
\quad(\%)\end{array}$ \\
\hline \multirow{5}{*}{1.} & \multirow{5}{*}{$\begin{array}{l}\text { Early Childhood } \\
\text { Development } \\
\text { Assessment Planning }\end{array}$} & Ability to develop a Daily Learning Implementation Plan & 34,37 \\
\hline & & $\begin{array}{l}\text { Understanding the objectives of early childhood } \\
\text { assessment }\end{array}$ & 43,75 \\
\hline & & Development of early childhood assessment instruments & 21,88 \\
\hline & & $\begin{array}{l}\text { Understanding the use of early childhood developmental } \\
\text { instruments }\end{array}$ & 43,75 \\
\hline & & Understanding the principles of assessment & 31,25 \\
\hline \multirow{3}{*}{2.} & \multirow{3}{*}{$\begin{array}{l}\text { Early Childhood } \\
\text { Development Data } \\
\text { Collection }\end{array}$} & Assessment instruments developed by the teachers & 37,5 \\
\hline & & Form of documenting early childhood development & 15,62 \\
\hline & & Continuity of assessment for early childhood development & 25 \\
\hline \multirow{2}{*}{3.} & \multirow{2}{*}{$\begin{array}{l}\text { Early Childhood } \\
\text { Development Data } \\
\text { Processing }\end{array}$} & $\begin{array}{l}\text { Completeness of data on early childhood development } \\
\text { measurement results }\end{array}$ & 25 \\
\hline & & $\begin{array}{l}\text { Teacher's understanding on early childhood development } \\
\text { data analysis techniques }\end{array}$ & 31,25 \\
\hline 4. & $\begin{array}{l}\text { Reporting of Early } \\
\text { Childhood Development } \\
\text { Assessment Results }\end{array}$ & $\begin{array}{l}\text { Teacher's understanding on early childhood development } \\
\text { reports covering early childhood development narratives } \\
\text { and trends }\end{array}$ & 37,5 \\
\hline & & Average Scores & 31,53 \\
\hline
\end{tabular}


The data on this questionnaire is supported by data obtained through the study of early childhood development assessment documents as follows:

Table 2. Types of Teacher Difficulties in Assessing Early Childhood Development with Assessment Document Study

\begin{tabular}{|c|c|c|c|}
\hline No. & Assessed Aspects & Sub-sub-Aspects Assessed & $\begin{array}{l}\text { Completeness of } \\
\text { Documents }(\%)\end{array}$ \\
\hline \multirow{4}{*}{1} & \multirow{4}{*}{$\begin{array}{l}\text { Early Childhood } \\
\text { Development } \\
\text { Assessment Planning }\end{array}$} & $\begin{array}{l}\text { Completeness of early childhood development } \\
\text { assessment plan in the Daily Learning } \\
\text { Implementation Plan }\end{array}$ & 31,25 \\
\hline & & $\begin{array}{l}\text { The Daily Learning Implementation Plan contains } \\
\text { indicators of children's assessment development in } \\
\text { accordance with the basic competencies }\end{array}$ & 31,25 \\
\hline & & $\begin{array}{l}\text { Availability of daily assessment instruments of child } \\
\text { development }\end{array}$ & 25 \\
\hline & & $\begin{array}{l}\text { Availability of various early childhood development } \\
\text { assessment instruments (cheques, portfolios, } \\
\text { anecdotal notes, sociometry) }\end{array}$ & 18,75 \\
\hline \multirow[b]{2}{*}{2.} & \multirow{2}{*}{$\begin{array}{l}\text { Early Childhood } \\
\text { Development Data } \\
\text { Collection }\end{array}$} & $\begin{array}{l}\text { Availability of documenting form of early childhood } \\
\text { development data }\end{array}$ & 18,75 \\
\hline & & $\begin{array}{l}\text { Completeness of early childhood development data } \\
\text { collection covering six aspects of development and } \\
\text { every early childhood }\end{array}$ & 25 \\
\hline \multirow[t]{2}{*}{3.} & \multirow{2}{*}{$\begin{array}{l}\text { Early Childhood } \\
\text { Development Data } \\
\text { Processing }\end{array}$} & $\begin{array}{l}\text { The completeness of data collected periodically } \\
\text { includes daily weekly, and monthly assessments }\end{array}$ & 25 \\
\hline & & Proof analysis on early childhood development data & 12,5 \\
\hline 4. & $\begin{array}{l}\text { Reporting of Early } \\
\text { Childhood Development } \\
\text { Assessment Results } \\
\end{array}$ & $\begin{array}{l}\text { Proof of report card/report on early childhood } \\
\text { development (periodically/incidental) }\end{array}$ & 25 \\
\hline & & Average Scores & 23,61 \\
\hline
\end{tabular}

The difficulty of teachers in assessing early childhood development is described in the following four things, namely:

First. Teachers have not been able to make proper and correct planning of early childhood development assessments. In this category, the types of teacher difficulties include lack of ability to draw up a Daily Learning Implementation Plan, not understand well about the use of assessment instruments and early childhood development assessment objectives, not being able to develop and use assessment instruments correctly, not understanding the principles of assessment, and the existence of subjective tendencies in making assessments.

The data of this study proves that most respondents do not include assessment plans and assessment instruments in the Daily Learning Implementation Plan. Additionally, the assessment plans and instruments used by the teachers do not conform to the assessment format. For example, teachers use note instruments of works, but in their implementation the teacher uses the format of a checklist instrument. Finding data related to the use of child development assessment instruments explains that teachers only use one instrument in assessing aspects of child development.

The same instrument is used for each type of assessment and does not conform to the theme of the activity. Further, teachers also do not provide assessment instruments in daily activities. Based on this data, it can be concluded that early childhood education teachers in Boleng Subdistrict do not well understand regarding the creation of a Daily Learning Implementation Plan and the practice of assessment instruments is not in accordance with the activity plan. This difficulty is in line with the teacher's lack of ability to develop child development assessment instruments. This research data shows that the teacher's difficulty in developing child 
development assessment instruments is related to the teacher's lack of ability in describingthe developmental indicators in accordance with the Child Development Achievement Level Standard (STTPA) into the assessment descriptor that will produce an assessment rubric. Operational verbs on indicators and assessment descriptors used by teachers are not yet correct. That is why, teachers only assess certain aspects of a child's development that are considered easy to judge such as the religious-moral, cognitive, linguistic, and artistic aspects of creativity.

Data related to the purpose of the assessment found that all respondents understood the purpose of the assessment only and limited to knowing the child progress covering the six aspects of development and as the basis information on the child development to the parents. In fact, the purpose of assessment is important as the basis for providing proper stimulation to the child. It means that the planning of learning or stimulation of children's development carried out by early childhood education teachers in Boleng Sub-district has not been based on the ability or actual condition of the child.

Data related to measuring early childhood development trends found that the assessment of development conducted by the teachers was not based on initial data as a baseline. That is the reason,why teachers have difficulty seeing the child's developmental trends after being stimulated. This is evidenced by the data that teachers do not conduct daily assessments consistently, but only grasp the development of children at the end of the semester as a decision on the results of child development.

The results of research related to the application of assessment principles found that there is a tendency of teachers to make assessments of early childhood development subjectively. This happens because the teacher does not have a clear assessment rubric as a reference in their assessment. Data on this, is evidenced by the fact that teachers rely only on the ability to remember in assessing the child's development, without having a clear daily assessment instrument and do not have periodic child development data.

Second, teachers have not been able to record or collect comprehensive child development data. This is due to the lack of assessment instruments developed by teachers. Moreover, teachers do not yet have a recording format or documentation of child development data. The available formats have not been filled out due to the teacher negligence. This is proved by data that teachers only assess certain aspects of development, namely physical-motor, cognitive, language and social aspects of emotional, while aspects of the religious and moral values and art development are rarely assessed by the teachers. Teachers do not assess some of these aspects on an ongoing basis.

Third, the processing of data from child development measurement has not been done continuously and is not based on complete data. The results of the documentation study prove that some teachers do not have detailed records of child development data and the assessments which conducted are still partial, both in terms of the aspects assessed and the timing of the assessment. Besides, researchers found out that teachers did not yet fully understand the qualitative data analysis techniques on child development. In these circumstances, teachers do not fully observethe qualitative data analysis methods, so the conclusions formulated are often contrary to the child's developmental data collected.

Fourth, reporting of early childhood development assessment results is made in the form of descriptions. As a result, teachers have difficulty in understanding child development trends over the time. The teacher only describes the child's developmental condition at a certain time and does not describe the child's developmental trends based on the previous situation. Followup reporting is limited to information for the parents and has not been utilized as a basis in preparing a learning-planning and mentoring the next child. 


\section{Causes of Early Childhood Teacher Difficulties}

The factors that originate four types of difficulty from the teachers in assessing aspects of early childhood development are: (1) pedagogic competence of early childhood education teachers is still below the standard. This finding is supported by data that teachers do not understand the stages in assessing aspects of early childhood development; (2) the academic qualifications of teachers that are not in accordance with the demands of the early childhood education teacher profession. Data on academic qualifications of early childhood education teachers in Boleng Sub-district as written in the following table:

Table 3. Academic Qualifications of Early Childhood Education Teachers in Boleng Subdistrict

\begin{tabular}{|l|l|c|}
\hline No & \multicolumn{1}{|c|}{ Academic Qualifications } & Amount \\
\hline 1. & High School / Equivalent & 12 \\
\hline 2. & Diploma in Education (other than Early Childhood Education) & 3 \\
\hline 3. & Diploma in Early Childhood Education & - \\
\hline 4. & Non-Educational Diploma & 8 \\
\hline 5. & $\begin{array}{l}\text { Strata 1/D4 in Education (other than Early Childhood } \\
\text { Education) }\end{array}$ & 2 \\
\hline 6. & Strata 1/D4 non-Education & 6 \\
\hline 7. & Strata 1/D4 Early Childhood Education & 32 \\
\hline \multicolumn{1}{|c|}{ Total Number } & \multicolumn{1}{|c|}{} \\
\hline
\end{tabular}

Data of this study found out that most teachers $(81.25 \%)$ who teach in early childhood education at Boleng Subdistrict, West Manggarai Regency is academically qualified as High School and non-early childhood education scholars; (3) the lack of belligerent power of teachers in developing their competences. This is evidenced by the lack of teachers 'involvement in activities related to the early childhood education, such as workshop/training on early childhood development assessment and socialization related to the early childhood education.

\section{Discussion}

Based on the data analysis results, researchers found out one fundamental problem experienced by the teachers in Boleng Sub-District, West Manggarai Regency, namely competence in making assessments for early childhood development is still categorized as low. The low competence in making early childhood development assessments is seen in the following matters, namely the ability to make an assessment plan only reaches $35 \%$, the ability to collect early childhood development data gains $26.04 \%$, the ability to process early childhood development data by only $28.12 \%$, and the ability to make early childhood development reporting only $37.5 \%$. The low competence is evidenced by a number of difficulties experienced by early childhood education teachers in making assessments for children's development.

The first stage in making an assessment is the planning stage. At this stage, there are several things that are done, namely determining the objectives of the assessment, the object of the assessment, the assessment techniques, developing the assessment instruments, and testing or revising the instruments. The fact transpires that the purpose of assessment made by early childhood education teachers in Boleng Sub-District only related to the aspect of summing-up, namely concluding and ensuring the level of children's development achievement.

Whereas the purpose of assessment is at least oriented to four things (Carol S. Lidz, 2003; Kusaeri \& Suprananto, 2012; Thakkar et al., 2021), namely keeping track, which is an effort that aims to keep the learning process in accordance with the plan; checking-up, which is to check the weaknesses experienced by the students and teachers during the learning process; finding- 
out is to discover the reason of weaknesses in the learning process; summing-up is to conclude and ensure the achievement of learning competencies by learners.

The object of assessment for early childhood development includes six aspects of development, namely religion-moral, physical-motor, cognitive, language, social emotional, and the art of creativity. These six aspects are one unity and complement to each other. Therefore, all learning and assessment activities in early childhood education must be related to these six aspects. Measurement of the six aspects of the child's development requires a variety of techniques and assessment instruments, each aspect has its own characteristics, some are concrete, but some are in abstract ways.

Therefore, such assessments require the competences of the teachers. Teachers should be able to develop and use a variety of assessment techniques and instruments. The use of varied assessment techniques and instruments allow teachers to obtain comprehensive data on child development. Thus, teachers can understand well the development of early childhood. Besides, teachers can design learning processes that suit the condition and needs of the children.

The second stage is the recording or collection of early childhood development data. This stage relates to the assessment instrument prepared by the teacher. If the instrument set up is invalid, then the collected data is also invalid. This has an impact on the invalidity of information about the child's development collected.

The third stage is data processing and assessment of measurement results. Data obtained from learners through measurement instruments, then collected, processed, analysed, and assessed. Research data proves that data processing and measurement of results have not been done continuously and are less based on complete data. This has an impact on the results of the assessment for children's development that is still incomplete. The child's developmental information obtained does not describe the actual circumstances of the child.

The fourth stage is the reporting of assessment results. Reporting the results of early childhood learning assessment is a form of school accountability for the parents or interested stakeholders to the child's self-development. The assessment report is not intended to please the parents or other parties, but to assist the child's development. That means that the results of reported child development assessment must be followed up jointly by all stakeholders with one common goal so that the child can develop optimally.

Measurement of teacher competence in assessing early childhood development can be done by measuring its ability to apply the principles of child development assessment. The Directorate of Early Childhood Education Development (Kemendikbud Republik Indonesia, 2015) stated about eight principles for children's development assessment, namely: First, educate. Assessment processes and results could become the basis for motivating, developing, and nurturing children to grow and develop optimally; Second. Sustainable. Assessment of children is made in a planned, gradual, and continuous manner to gain an idea of the growth and development of the child; Third. Objective. Assessments are based on clear procedures and criteria, but not influenced by the subjective elements of the assessor. Thus, the assessment describes the information or actual data.

Fourth. Accountable. Assessment is carried out in accordance with the clear, precise, and scientifically accountable procedures and criteria. Fifth. Transparent. Assessments are conducted in accordance with the well-defined and systematic procedures. The assessment results can be accessed by parents and all relevant stakeholders. Sixth. methodical. Assessments are conducted regularly and programmatically in accordance with the growth and development of the child using a variety of appropriate instruments; Seventh, comprehensive. Assessment covers all aspects of the child's growth and development both attitudes, knowledge and skills. The assessment accommodates all cultural, linguistic, socio-economic diversity, including 
children with special needs; Eight. Meaningful. The assessment results provide useful data or information for the children, parents, teachers, and others subjects relevant to the information.

Teachers who possess the competences in assessing the development of early childhood can carry out the assessment activities appropriately and correctly. However, most teachers in Boleng sub-district are not able to assess early childhood development correctly. This is due to the lack of pedagogical competence of teachers in developing child development assessment instruments. This poor condition is also caused by inadequate readiness in works and fighting power in developing the ability to assess the early childhood development. This is demonstrated by the lack of teachers' involvement in educational activities and trainings, or workshops related to the early childhood learning.

Whereas most teachers have academic qualifications that are not in accordance with the demands of the early childhood education teacher profession. Therefore, teachers should be more active to attend education and training related to the early childhood profession. Besides, teachers have competence and skills in teaching and educating early childhood. There is research that displays that work readiness turn out to have a significant effect on the future orientation of teachers' careers (Bradbury, 2014;Levine-donnerstein \& Marx, 2015).

Low work readiness factor causes the orientation of career development as a teacher to be less clear, especially for teachers who do not have competences. All teachers on this situation, have obstacles in teaching-learning because they do not know what to do, how to do, and what the benefits of the work they have done. Thus, the future orientation of teacher's career is floating or absolutely without career orientation. Another study also found that teacher's fighting power significantly affects the future orientation of teachers' careers (Ntuli et al., 2012;Patricia et al., 2019).

The lack of early childhood education teacher work readiness could decrease teacher's fighting power. One's success in living a life is largely determined by the level of fighting power and perseverance. Early childhood teachers who keep high fighting power appear in an effort to continuously develop themselves with a number of competencies needed. At this level, early childhood education teachers need to have a commitment to plan and continuously develop themselves.

\section{Conclusion}

Early childhood education teachers must have competence in assessing early childhood development. The results of this study found that the competence of early childhood education teachers in Boleng Sub-District, West Manggarai Regency in assessing the development of early childhood is still categorized as lacking. This is evidenced by a number of difficulties confronted by the teachers in making assessments of children's development. The difficulties found can be categorized in four stages, namely assessment planning, data collection, data analysis, and reporting and follow-up the assessment results.

There are three causes of difficulty for early childhood education teachers in assessing the early childhood development, namely: (1) lack of pedagogic competence, (2) teacher academic qualifications that are not in accordance with the professional guidance of Early Childhood Education teachers, and (3) lack of fighting power and perseverance of the teachers in developing their competencies.

Based on the findings of this study, the recommendation for further research is: (1) develop a training model that can improve the pedagogical competence of early childhood education 
teachers; (2) the teachers are required to attend workshops or teacher training to develop authentic measurement and assessment instrument regarding five aspects of early childhood development, namely moral-religious, cognitive, language, socio-emotional, and art-creativity aspects.

\section{References}

[1] Bradbury, A. (2014). European Early Childhood Education Learning , assessment and equality in Early Childhood Education ( ECE ) settings in England. European Early Childhood Education Research Journal, February 2015, 37-41. https://doi.org/10.1080/1350293X.2014.912897

[2] Brian Reichow, Brian A. Boyd Erin E. Barton, S. L. O. (2016). Handbook of Early Childhood Special Education. In S. L. O. Brian Reichow, Brian A. Boyd Erin E. Barton (Ed.), New York: Springer Science (pp. 541-563). https://doi.org/10.1007/978-3-319-28492-7_28

[3] Carol S. Lidz. (2003). Early Childhood Assessment. United States of America : John Wiley \& Sons, Inc.

[4] Catherine E. Snow and Susan B. Van Hemel. (2008). Early Childhood Assessment: Why, What, and How. In United State of America: The Nasional Academy of Science (Vol. 4, Issue 3).

[5] Jones, S. M., Zaslow, M., Darling-Churchill, K. E., \& Halle, T. G. (2016). Assessing early childhood social and emotional development: Key conceptual and measurement issues. Journal of Applied Developmental Psychology, 45, 42-48. https://doi.org/10.1016/j.appdev.2016.02.008

[6] Kamppi, D., \& Gilmore, L. (2010). Assessing cognitive development in early childhood: A comparison of the bayley-III and the stanford-binet, fifth edition. Australian Educational and Developmental Psychologist, 27(2), 70-75. https://doi.org/10.1375/aedp.27.2.70

[7] Kemendikbud Republik Indonesia. (2014a). Peraturan Menteri Pendidikan dan Kebudayaan Republik Indonesia Nomor 137 Tahun 2014 Tentang Standar Nasional Pendidikan Anak Usia Dini. Jakarta : Kemendikbud RI.

[8] Kemendikbud Republik Indonesia. (2014b). Peraturan Menteri Pendidikan dan Kebudayaan Republik Indonesia Nomor 146 Tahun 2014 tentang Kurikulum 2013 PENDIDIKAN ANAK USIA DINI. Jakarta : Kemendikbud RI, 53(9), 1689-1699. https://doi.org/10.1017/CBO9781107415324.004

[9] Kemendikbud Republik Indonesia. (2014c). Standar Nasional Pendidikan Anak Usia Dini. Jakarta : Peraturan Menteri Pendidikan Dan Kebudayaan Republik Indonesia, 13.

[10] Kemendikbud Republik Indonesia. (2015). Penilaian Pembelajaran Pendidikan Anak Usia Dini. Jakarta : Direktorat Jenderal Pendidikan Anak Usia Dini Dan Pendidikan Masyarakat \& Direktorat Pembinaan Pendidikan Anak Usia Dini, 021.

[11] Kim, H. K., \& Han, H. S. (2015). Understanding early childhood teachers' beliefs and self-stated practices about social competence instructional strategies in the context of developmentally appropriate practice: a comparison of preservice and in-service teachers in the United States. European Early Childhood Education Research Journal, 23(4), 476-496. https://doi.org/10.1080/1350293X.2015.1087152

[12] Kusaeri, \& Suprananto. (2012). Pengukuran dan Penilaian Pendidikan. Yogyakarta: Buku Graha Ilmu, 01(01), 1-10.

[13] Lee, Y. J., \& Recchia, S. L. (2016). Zooming In and Out: Exploring Teacher Competencies in Inclusive Early Childhood Classrooms. Journal of Research in Childhood Education, 30(1), 1-14. https://doi.org/10.1080/02568543.2015.1105330

[14] Levine-donnerstein, D., \& Marx, R. W. (2015). Assessing Approaches to Learning in School Readiness : Comparing the Devereux Early Childhood Assessment to an Early Learning StandardsBased Measure. AERA Open, 1(3), 1-15. https://doi.org/10.1177/2332858415593923

[15] Maman, U., Sugiarti, Y., \& Ratnawati, S. (2016). Learning system design using knowledge management systems to improve the competency of early childhood education teachers. Proceedings 
of 2016 4th International Conference on Cyber and IT Service Management, CITSM 2016. https://doi.org/10.1109/CITSM.2016.7577577

[16] Matthew B.Miles, A. Michael Huberman, J. S. (2014). Qualitative Data Analysis, A Methods Sourcebook, Third Edition. United State of America : Sage Publications.

[17] Mundia, K., \& Heru, S. (2020). Kompetensi Pedagogik Guru dalam Melaksanakan Penilaian Pembelajaran Anak Usia Dini Abstrak. Jurnal Obsesi : Jurnal Pendidikan Anak Usia Dini, 4(2), 900 912. https://doi.org/10.31004/obsesi.v4i2.478

[18] Ngoun, C., Mey, P. De, Baesel, K., Khoeun, R., \& Saem, L. (2020). Early Human Development Cambodian Developmental Milestone Assessment Tool ( cDMAT ): Performance reference charts and reliability check of a tool to assess early childhood development in Cambodian children. Early $\begin{array}{llll}\text { Human Development, } & \text { 141(August } & \text { 2019), }\end{array}$ https://doi.org/10.1016/j.earlhumdev.2019.104934

[19] Ntuli, E., Kyei-blankson, L., \& State, I. (2012). Teacher Assessment of Young Children Learning with Technology in Early Childhood Education. International Journal of Information and Communication Technology Education, $\quad$ 8(December), 1-10. https://doi.org/10.4018/jicte.2012100101

[20] Owen, K., \& Barnes, C. (2021). The development of categorization in early childhood: a review. Early Child Development and Care, 191(1), 13-20. https://doi.org/10.1080/03004430.2019.1608193

[21] Patricia, S., Londoño, V., Bernal, A., Soria, M. De, \& Rivas, S. (2019). Early Childhood Development and Education: Theoretical Convergences and Divergences. International Education Studies, 12(7), 1-9. https://doi.org/10.5539/ies.v12n7p1

[22] Pushparatnam, A., Luna Bazaldua, D. A., Holla, A., Azevedo, J. P., Clarke, M., \& Devercelli, A. (2021). Measuring Early Childhood Development Among 4-6 Year Olds: The Identification of Psychometrically Robust Items Across Diverse Contexts. Frontiers in Public Health, 9(February), 111. https://doi.org/10.3389/fpubh.2021.569448

[23] Rao, N., Sun, J., Richards, B., Weber, A. M., Sincovich, A., Darmstadt, G. L., \& Ip, P. (2019). Assessing Diversity in Early Childhood Development in the East Asia-Pacific. Child Indicators Research, 12(1), 235-254. https://doi.org/10.1007/s12187-018-9528-5

[24] Rhoad-Drogalis, A., Sawyer, B. E., Justice, L. M., \& O'Connell, A. A. (2018). Assessing Learning Behaviors in Early Childhood Special Education Classrooms. Early Education and Development, 29(4), 450-466. https://doi.org/10.1080/10409289.2018.1460982

[25] Sum, T. A., Emilia Graciela, \& Mega Taran. (2020). Kompetensi Pedagogik Guru PENDIDIKAN ANAK USIA DINI dalam Perencanaan dan Pelaksanaan Pembelajaran Abstrak. Jurnal Obsesi : Jurnal Pendidikan Anak Usia Dini, 4(2), 543-550. https://doi.org/10.31004/obsesi.v4i2.287

[26] Syafdaningsih, T. S. (2020). Development of authentic assessment model in the field of mathematic for early childhood in Palembang City. IOP Conf. Series: Journal of Physics: Conf. Series. https://doi.org/10.1088/1742-6596/1480/1/012077

[27] Thakkar, S., Chavda, P., Vahora, R., \& Patel, R. (2021). Image-based assessment in undergraduate dermatology curriculum: A step toward competency-based medical education. Medical Journal Armed Forces India, 77, S134-S139. https://doi.org/10.1016/j.mjafi.2020.11.005

[28] van Dijk, M. (2021). A complex dynamical systems approach to the development of feeding problems $\begin{array}{llll}\text { in early childhood. } & \text { Appetite, } & 157 \text { (October 2020), }\end{array}$ https://doi.org/10.1016/j.appet.2020.104982

[29] Varela Londoño, S. P., Martínez de Soria, A. B., \& Rivas, S. (2019). Early Childhood Development and Education: Theoretical Convergences and Divergences. International Education Studies, 12(7), 1. https://doi.org/10.5539/ies.v12n7p1

[30] Wolf, S., Halpin, P., Yoshikawa, H., Dowd, A. J., Pisani, L., \& Borisova, I. (2017). Measuring school readiness globally: Assessing the construct validity and measurement invariance of the International Development and Early Learning Assessment (IDELA) in Ethiopia. Early Childhood Research Quarterly, 41(May), 21-36. https://doi.org/10.1016/j.ecresq.2017.05.001

[31] Wulansari, V. I. \& W. (2018). Pentingnya Penilaian Pendidikan Karakter Anak Usia Dini. Proceeding of The ICECRS, 1(3), 197-204. https://doi.org/10.21070/picecrs.v1i3.1396 